\title{
RIGHTS AND RELIGIOUS BELIEF IN MAINTAINING PRISON SOCIAL ORDER
}

\author{
Elijah Tukwariba Yin ${ }^{1}$, Peter Atudiwe Atupare ${ }^{2}$, Nelson Kofie ${ }^{3}$, \\ Linda Peasah Owusu ${ }^{4}$ and Thomas Prehi Botchway ${ }^{5}$
}

\begin{abstract}
$\mathrm{T}$

his paper argues that it is not the prison rules and regulations that alter the behaviour of inmates but rather the ideological justification of their religious faith. The article draws upon the social constructionist theory of reality to underpin the discussion of the data. Data was gathered through in-depth interviews and the distribution of semistructured questionnaires. When analysed, the data revealed that although inmates had the right to practice the precepts of their religious faith as defined in law, in practice, these religious rights were not entirely observed. The partial recognition of these rights divulges that the principle of humane treatment underpinning the respect for rights in prison was ignored and reduced to mere formal respect for rules. Besides, the data disclosed that inmates rarely attributed the change in their personality to the impact of prison rules and regulations, but rather to the transformative power of their religion.
\end{abstract}

Keywords: Rights, Religion, Prison, Social Construction, Social Order

\footnotetext{
* We acknowledge the review report of Prof. Diamond Ashiagbor of Kent Law School. Diamond reviewed this paper during the Cardiff Law and Global Justice Workshop held in 2018 at Ghana Institute of Advanced Legal Studies, Accra, Ghana.

1 Faculty of Law, University of Cape Coast, Cape Coast

2 Faculty of Law, University of Cape Coast, Cape Coast

3 Northern Virginia Community College, U.S.A.

4 Center for Migration Studies, University of Ghana, Legon

5 Department of Political Science Education, University of Education, Winneba
} 


\section{Introduction}

Human rights are rights inherent to all persons, irrespective of sex, religion, race, language, nationality, ethnicity, or any other status ${ }^{6}$. These rights imply a particular view of what a human being is and his/her relationship to the state, community, and other persons. The human rights corpus is not a faith or a set of normative principles suspended in outer space; it borders on matters that affect the daily routine politics of people and institutions. Hence, some legal scholars have argued that all individuals should have the same opportunities to participate in the construction of the institutions and practices of the polity and should be equal before the law ${ }^{7}$. This, of course, is the ideal. Convicted criminals forfeit certain rights such as the right to freedom and liberty, movement, and privacy. Yet, are still entitled to the following: the right to a fair trial, protection from retrospective laws, the right from enslavement, the right to freedom from torture, the right to life, and religion. It is for the case of religion that international ${ }^{8}$ covenants and nationa $\left.\right|^{9}$ ordinances and policies make provision for prisoners to practice their religion.

6 Universal Declaration of Human Rights, 2015

7 See Kymlicka, 1995

8 Article 18 of the Universal Declaration of Human Rights provides that: Everyone has the right to freedom of thought, conscience and religion; this right includes freedom to change his religion or belief, and freedom, either alone or in community with others and in public or private, to manifest his religion or belief in teaching, practice, worship and observance. Article 18 of the United Nations International Covenant on Civil and Political Rights (Hereafter referred to as ICCPR) also offers for religious rights and freedom. In the second paragraph of the Covenant, it specifically provides that: No one shall be subject to coercion which would impair his freedom to have or to adopt a religion or belief of his choice. Article 27 of the same ICCPR provides that: In those States in which ethnic, religious or linguistic minorities exist, persons belonging to such minorities shall not be denied the right, in community with the other members of their group, to enjoy their own culture, to profess and practise their own religion, or to use their own language. The United Nations Standard Minimum Rules for the Treatment of Prisoners (1955) make specific reference to the need for prison authorities to allow prisoners to observe their religion and to have access to a minister of that religion: 41. (1) If the institution contains a sufficient number of prisoners of the same religion, a qualified representative of that religion shall be appointed or approved. If the number of prisoners justifies it and conditions permit, the arrangement should be on a full-time basis. (2) A qualified representative appointed or approved under paragraph (1) shall be allowed to hold regular services and to pay pastoral visits in private to prisoners of his religion at proper times. (3) Access to a qualified representative of any religion shall not be refused to any prisoner. On the other hand, if any prisoner should object to a visit of any religious representative, his attitude shall be fully respected. 42 . So far as practicable, every prisoner shall be allowed to satisfy the needs of his religious life by attending the services provided in the institution and having in his possession the books of religious observance and instruction of his denomination.

9 Part eight (8) of the Prison Regulations of 1958 on divine service states as follows: (49) The Chaplain, or such other person as may be appointed by him with the occurrence of the officer-in-charge of the prison, shall perform the appointed service of his denomination every Sunday, and on Christmas Day, and 
The essence of these legal instruments is to provide the practical frameworks for inmates to meet the set mandates of prisons. Also, these prison ordinances ${ }^{10}$ aim to control the behaviours of inmates - the clothes inmates should wear, the number of visitors inmates should receive within a week or a month, their diet, and bedding. The idea is to alter the behaviour of inmates for possible reintegration into mainstream society. There are schools of thought that hold that the strict enforcement and implementation of these prison rules and regulation make inmates comply with the prison conditions and to the dictates of prison officers. ${ }^{11}$ This paper examines the interplay between inmates' right to their religion and the secular prison bureaucracy and what constitutes the subjugation of inmates to the prison bureaucracy. It is argued that it is not the official prison rules and regulations that alter inmates' behaviour and maintain prison order but rather the ideological justification of their religious faith.

on Good Friday; and moral and religious instruction shall be given to prisoners who are willing to receive it. (50) Ministers of any recognised religion may be admitted at reasonable and proper times to the prison to visit prisoners who may wish their services. Like the Prison Regulations of 1958, Chapter IX of the 1960 Prisons Standing Orders state as follows: (382) Arrangements shall be made by Superintendents and Officers-in-Charge for Divine Services for all the recognised religious denominations to be held on Sunday mornings and afternoons. The times of these services shall be decided by the Superintendent or Officer-in-Charge in consultation with the Minister concerned. (383) Attendance of prisoners at these services is voluntary, but no prisoner shall be allowed to attend the Service of any denomination other than that he declared to be his persuasion on admission. (385) No prisoner shall be allowed to change his religion without reference to the Minister of his declared religion and the Minister of the religion to which he wishes to change. (386) Prisoners attending Divine Service shall be properly clothed. (388) Arrangements shall be made for an additional service or period of instruction to be held for each religion on one evening during the week. The time of such service or instructional period shall be arrange by the Superintendent or Officer-in-Charge in consultation with the Minister of the religion concerned. (389) All such services or periods of instruction shall cease at, or before, 7 p.m. and sufficient officers shall be present to maintain good order and discipline. The Prison Service Decree, 1972 (NRCD) also recognizes the need for religious freedom and religious tolerance as well as access to outside clergies at various times. Section 40 - Religious Observances (1) No prisoner shall be hindered in the reasonable exercise of his religious observances. (2) Every prisoner shall be entitled to attend every religious service of his faith or denomination held within the prison. (3) Ministers, howsoever known, of any religious faith or denomination shall be admitted at reasonable and proper times to visit prisoners who may wish their services. (4) Moral and religious education instruction shall be given to prisoners who are willing to receive it. (5) This section shall apply notwithstanding that a prisoner in undergoing punishment for offence against prison discipline. Hierarchically superior to all these laws, and taking normative priority over them, is the 1992 Constitution of the Republic of Ghana, which guarantees all persons freedom of religion. Article 21 and 26 clearly stipulates that: 21. (1) All persons shall have the right to- (a) ... (b) freedom of thought, conscience and belief, which shall include academic freedom; (c) freedom to practice any religion and to manifest such practice; ...26 (1) Every person is entitled to enjoy, practice, profess, maintain and promote any culture, language, tradition or religion subject to the provisions of this Constitution.

10 Prison Regulations 1958, Prison Service Decree 1972, NRCD 46, Prison Standing Orders 1960.

11 See Cullen \& Jonson, 2012 
The prison (a secular state agency, rational-legal bureaucracy) and religion (Church/ Mosque/sacred space) are separate entities. In principle, they are antithetical. The prison is a confinement centre for people deemed dangerous to society. It is meant to punish and reform offenders. ${ }^{12}$ Religion, on the other hand, creates a sense of belonging based on shared norms and moral values. ${ }^{13}$ Apart from these norms and moral values, religious codes guide people's behaviour and actions by helping them to become useful members of society. ${ }^{14}$ The prison is about "bad" things: criminality and chastisement whilst religion is about good things: sacredness and dedication. The inmate is considered a social outcast, eschewed by the public, "but the religious experience of 'conversion' promises to transform the prison experience from 'you are caught' to 'you are free'". ${ }^{15}$ That is, from control over the body to spiritual redemption. It is important to note that, despite the differences, it is the state bureaucracy that provides the space for religious practices. Seemingly juxtaposed in principle and practice, how (and by what means) have the prison administration negotiated the spaces and processes within the boundaries of the state law for inmate's religious activities?

The 1992 Constitution of Ghana grants inmates the free exercise of their religion, but there is nothing in the constitution that stipulates that the government should institute religion as a "tool" of rehabilitation. If religion is a governmental "tool" then it is an ideology - a body of doctrine - aimed to pacify inmates to behave themselves. It is a fact that Ghanaians are overwhelmingly Christians and Muslims in a democratic country, but the nation-state of Ghana is not theocratic. If the practice of religion is a right, then the government needs not use religion as a "tool" of rehabilitation. Government agencies and civil servants must remain neutral in the execution of their services to the public. Ankaful Maximum Security Prison (hereafter as AMSP), which is the study setting, is not in the business of using religion as a "tool" to rehabilitate inmates. Its task - through laws and policies - includes the facilitation of inmates' rights to free exercise of their religious beliefs within reasonable means. It is the government's mandate to provide a religious facility for inmates to willingly, without coercion, to practice (or to abstain from) religion in the facility. To this extent, religion remains in the sphere of civil society within the confines of prison. ${ }^{16}$

\footnotetext{
12 The work of Clear et al., 1992 detailed this position 13 See Durkheim, 1912 14 See Stansfield, Mowen, O'Connor \& Boman, 2017 15 See footnote 10

16 See Yin's PhD thesis on religion as an organizing principle in Ankaful Maximum Security Prison.
} 
Against this backdrop, it is convenient to state that religion and human rights are deemed to have complex and inextricable relationship. According to Witte and Green ${ }^{17}$, most religions have supported repression, violence, and prejudice. Despite this, most religions have also played critical roles for universal human rights. These religions have provided the essential scales and sources of dignity and responsibility, respect and shame, restraint and regret, restitution and reconciliation that human rights regime needs to flourish and survive in any culture. This makes the examination of human rights and religious belief in the context of imprisonment timely.

\section{Theory and method}

In examining the rights of inmates in the context of their religiosity and what constitutes their subjugation to the prison bureaucracy, the social constructionist theory of reality by Berger and Luckmann ${ }^{18}$ was used to underpin inmates' explanation of their imprisonment through their religious realities. The central theme of the theory is that interactions by individuals and groups in a social system generate, over time, concepts of each other's actions. Through this, meanings are created, negotiated, sustained, and modified. ${ }^{19}$ In other words, concepts become accustomed to mutual roles played by the actors. Through socialization these roles become institutionalized. Burr submits that our identity originates not from within a person but from the social environment. ${ }^{20}$ Through significant others such as family members, friends, and other individuals who intermediate the reality of society, socialization takes place.

Religion is a socially constructed reality. Inmates' view of religion becomes highly dependent on narratives and their social experiences. Inmates may develop their religious identity while being in the 'free' society or prison. This identity is dependent on the meaning and interpretation they give to their object of worship or deity. Out of this, inmates maintain interdependence and their individuality in respect of the deity they pay allegiance to. In addition, inmates' identity originates not from themselves but from their social setting. Through their interactions with significant others, inmates construct their religious reality. That is, how they comprehend and how they think religion contributes to their prison life based on their lived experiences.

The data on which this paper is based comprises primary sources. The primary empirical data were gathered through in-depth interviews, informal interactions, and the review and assessment of the results of semi-structured questionnaires of inmates in

17 See Witte, J., \& Green, M. C worked on Religion and Human Rights.

18 Berger and Luckmann introduced the social constructionist theory of reality, 1967.

19 See Schwandt, 2003

20 See Burr, 2003 
Ankaful Maximum Security Prison, Ghana. AMSP was established in 2011 to house high sentence and high profile criminals. It was a way of decongesting the overcrowded prisons in Ghana. The facility is on a stretch of land size of 1,800 feet by 1,800 feet. According to Attafuah (2013), the cells of AMSP measures 16 feet 5 inches by 10 feet 10 inches. It was observed that ventilation was not a major problem though the cell temperature $(30 \mathrm{oC})$ is higher than the temperature of a normal room (Average of $23 \mathrm{oC}$ ). Each cell holds between six (6) to ten (10) inmates. However, most cells accommodated not less than 8 inmates. The prison has a capacity of 2000 inmates with six (6) blocks labelled A-F. 'A' and ' $F$ ' blocks have a capacity of 200 each whilst ' $B$ ' to 'E' blocks have 400 inmates capacity with 40 cells. However, at the time of this research, only three blocks were in use with inmates' total population of 802 (as of 12 December, 2016). The 'A' block houses 79 inmates, 'B' block houses 331 inmates, with 'C' block 392 inmates. At the time of this study, the number of commissioned officers was 24 whilst subordinate officers were 99 summing up to 123 warders, as against 802 inmates. Out of the inmate population of 802, a sample size of 169 inmates was drawn of which 147 returned their semi-structured questionnaire. The respondents (inmates) were selected using simple random and systematic sampling approaches. The number of participants for the qualitative aspect of the study was 34 . They included inmates, prison officers, visiting Clergy, and ex-convicts. However, not all responses were used in this study since this formed part of a major study. Only inmates participated in the semi-structured questionnaire. The qualitative data were analysed thematically whilst the quantitative data were analysed using the Statistical Package for the Social Sciences (SPSS) software version 22. Descriptive statistical analysis was done using percentages. The names used to represent participants in the data discussion do not represent the true identity of participants in the prison facility. The Code of Ethics approved by the International Sociological Association Executive Committee was highly considered. This study was given ethical clearance from the University of Cape Coast institutional review board. Clearance was also sought from the Prison Headquarters in Accra, Ghana.

\section{Inmates, religion, and affiliation}

This study investigated the religious practices of inmates before and during their imprisonment. This helped to compare inmates' previous religious practices with their present prison religious practices. The data revealed that almost all inmates had some sort of religious affiliation before conviction. The data showed that $56.4 \%$ were Christians, $32 \%$ were Muslims, whilst $11.6 \%$ were traditionalists. However, after conviction $68 \%$ identified themselves as Christians, $25.9 \%$ as Muslims, whilst $6.1 \%$ as Traditionalists. Through casual conversations, inmates stated the reasons for their affiliations as thus; 
I was born into the religion ...my environment was dominated by my present religion ...the school I attended was a mission school so I followed that faith... I became converted through the preaching of an evangelist in the prison.

This was confirmed by another inmate:

....My parents and friends were Muslims... In the town I lived in, most of the residents were Muslims. So I also became a Muslim.... (Fred, inmate, religious leader, 2017)

These findings corroborate with Gaur ${ }^{21}$, who found that before inmates' conviction many of the religions followed by these inmates were the religions of their families. The social setting of inmates played a critical role in determining their religious affiliation. Implicitly, these inmates were socialized into the beliefs, teachings, and practices at an early age. Many of these inmates did not change from the religions of their parents, as was evident in their present affiliation. All these authenticate the importance of social structures in determining a person's religious affiliation. An indication that the processes of interaction with social structures are shaped at an early age by some other social structures, particularly education, religion, but subject to family and other social relationships. With Ghana being a religion-saturated society, very few individuals can escape the pervasiveness of religion of all sorts in daily life and living. It is not surprising that many inmates enter prison already knowledgeable about the significance of religion in their lives.

For how frequently inmates attended religious services before conviction, $29.9 \%$ said only on High Holy days such as Christmas and Easter, $20.4 \%$ said once a week, that is, every Saturday or Sunday, $3.4 \%$ said once in a month, $2.7 \%$ said always, whilst $43.6 \%$ did not attend religious services. This was similar among Muslim inmates as $85.7 \%$ only visited the mosque during the month of Ramadan. These data imply that the majority of inmates were infrequent attenders of religious services before their conviction. The state of inmates' religiosity was different in their present predicament as $67.3 \%$ said they always attended religious services. The question is, what has accounted for this change? The answer is perhaps found in Agnew's ${ }^{22}$ argument that individuals are more vulnerable to a transformative dogma inside the prison environment. This is based on the assumption that the prison setting creates a small population where amalgamation of issues congregate to generate the unique need for and access to change.

21 Gaur examined the role of religion in prison in India.

22 Agnew, 1992 
Comparing the data on religious affiliation before conviction with religious affiliation after conviction, it was clear that some inmates had switched faith in prison. This finding is not different from Gaur (2011), that during imprisonment whilst some inmates maintained and strengthened their faith in a deity, others either gave up on the religion or switched their faith to other religions. The underlying factors for these conversions were varied. These include the inmate's encounter with a religious Civil Society Organisation (CSO), prison evangelism, and personal revelation and discovery of a deity. In the course of the in-depth interviews, two inmates had this to say:

...I was a Muslim when I came to prison. There were some Christians in my cell who used to preach in the cell. I listened to their words and changed from being a Muslim to a Christian. (Fred, inmate, religious leader)

My parents were idol worshippers so they introduced me to that type of worship. For me, there was nothing like going to church. ...I started attending church services when I first came to prison. That was the first time I heard about the word of God. ... and listening to the word of God inspired me. (Moses, inmate, religious leaders)

The qualitative data show that inmates' religious affiliation either before or after the conviction was influenced by their previous environment, as well as their present situational interactions. It also indicates that inmates' religious socialization can be attributed to their family and friends or the socio-cultural environment in which they found themselves. The data further revealed inmates' rediscovery of self. This could be the result of a traumatic prison experience. This also shows how religion in Ghana is peripheral to the daily lives of citizens. All these points to how inmates explain away their religious realities through the internalization of previous social experience. It also solidifies the point that religion is a socially constructed reality based on narratives and social experiences. ${ }^{23}$ Out of this, inmates develop their own identity dependent on the interpretation and the meaning they give to their object of worship.

The data further suggest that the prison setting provides a social arena of an unavoidable mixture of plural normative religious orders. These normative orders appeared to be overlapping with each other in the prison bureaucracy. This pluralism within AMSP has provided the opportunity to have some kind of a hybrid religious space. The practical implication of this is seen in terms of how inmates with Christian religious affiliation relate and view a Muslim or a traditionalist inmate, and vice versa. It appeared that AMSP

23 See Berger \& Luckmann, 1967

8 || UCC Faculty of Law Journal 
comprehends it as necessary to provide a "religious space" for inmates to express their religious beliefs, but no spaces for skills acquisition and development. ${ }^{24}$ This makes religion a bureaucratic priority. Why? Perhaps, the prison administration understands how religion contributes to the subjugation of inmates.

Inmates who may not be religiously affiliated but are thinking of becoming so, or inmates with religious affiliation but who wish a change, may ask questions about which religious regime meets their needs and orientation. This provides the opportunity for inmates to choose from the multiple religious bodies at AMSP. This is evident in the conversion of inmates from one religious faith to another and even conversion within the same religion. The challenge posed to any of these religious bodies (Christianity, Islam, and Traditional religions) in prison is that they are rivals to each other as they share and profess dissimilar beliefs. Amidst this rivalry, the members of these faith communities are accommodating each other.

Notably, this religious plurality in AMSP is not about how inmates are co-existing in this social arena but the seemingly fluid diversity that exists in the various religious practices - a day of worship, different religious books, the different approaches to worship and beliefs, etc. in an otherwise carceral institution. Invisibly, these inmates' religious practices and demands proffer a competing claim of authority. Pluralism in this context speaks not so much about the unflinching devotion of inmates to the worship of their various deities but the fact that inmates' initiated religion is the only mode of self-expression in AMSP.

\section{Prison rules, rights, and religious faith}

The practice of religion in prison is not a favour conferred on prisoners in Ghana. It is part of the body of rights to be claimed by all inmates and respected by the prison administration. Not because they are prisoners, but because they are human beings who deserve some dignity ${ }^{25}$; no more or less granted to other citizens. The evidence available suggests that there is freedom of worship in prisons in Ghana; different Clergy with dissimilar faiths are permitted to visit their adherents in prison. These are entrenched rights, as the prison cannot impede the practice of religion. ${ }^{26}$ However, these rights are not without limits. The exercise of such religious rights must conform to prison regulations, and also not in contravention of the rights of other inmates. In this paper, this type of right is described as a "right of no right". Such rights are exercised under strict control. The following questions are relevant in this context: Is there a link between the rule limiting religious practices and a genuine prison interest? And do inmates have 24 See fn 14.

25 See Zellick, 1978

26 See Stansfield, Mowen, O'Connor, \& Boman, 2017 
alternative ways of exercising such religious rights?

Per prison regulations, inmate's subscription to religion is enshrined in their legal rights. Though a right, there are restrictions and determinants of such rights. The prison determines the time for worship, and which visiting clergy is qualified to proselytize within the prison. The interview report reveals that the implementation of prison rules was in circumspection of the social order of the prison. This manifested in inmate's switch of faith without recourse to the prison chaplain or prison regulations. Switching of faith and religious affiliation was a normal practice within the prison, accepted by both officers and inmates. An ex-convict stated;

... I did not tell any officer that I had changed my faith or my church in the prison...

The data appeared contradictory to section 385 of Prison Standing Order 1958, whilst to some extent, it aligned with section 40 (1) of the Service Decree of 1972 . This is because, for an inmate to change his faith, it must be subjected to the approval of the prison clergy, but this was hardly so. It was an accepted informal rule for prisoners to switch faith. An informal discussion with the prison chaplain revealed that the switch of faith without following laid down procedure did not amount to any challenge within the facility. It was a normal practice among inmates. This shows the contestation of formal and informal prison rules, and how at times prison administration circumvents the legal arena for penal management. This further shows an uneven legal framework that lacks instrumental cohesion, all operating within the same social field.

Against this backdrop discussed, inmates were asked whether they were aware of their religious rights or not and whether they were able to practice these rights. The quantitative survey revealed that $61.2 \%$ of inmates were aware of such rights in prison whereas $38.8 \%$ claimed they were not aware. It was revealed that inmates became aware of such rights through their interaction with peers, prison officers, and religious CSOs. With this rate of awareness, $93.9 \%$ of inmates were able to practice their religion, whilst $6.1 \%$ were unable to do so. The affirmative nature of the data suggests religious liberty in prisons in Ghana. The data further infer that, whether inmates were aware of their religious rights or not, such knowledge did not determine their chances of practicing their religion of choice. This takes cognisance from the interest theory of rights by Jeremy Bentham, as against the will theory, that a prisoner having the right to practice religion means it is in the interest of the inmate and the prison as a whole, and the prison has a duty to protect and provide such rights. This analysis validates claim rights as discussed by Hohfeld ${ }^{27}$

27 See Hohfeld, 1919 
and further detailed by Jones ${ }^{28}$ In this context, the prisoner is the right holder whilst the state bureaucracy becomes the right provider. Simply put, the prison is the facilitator of inmate's religious rights. These religious rights expressed by inmates are privilegerights, in the sense of their non-forbiddenness. Inherently, the empirical data suggest that inmates have a pair of privilege rights - that is, the right to practice religion and the right to stay off religion. These rights are subjected to the legal distribution of freedoms. As the legal orders empower the prison to exercise their authority over inmates, yet at the same time define their limits. This insight provides a meaningful connection between the inmate's re-discovery of self through religion; and the realisation of the human right to freedom of religion within the prison.

Though inmates were able to practice their religion of choice, these practices were without challenges. During the interviews, inmates posited that they worshipped freely, however, there were times their religious observances had to be halted or suspended due to prison administrative issues and rigid rules. This meant that there were times daily prison activities impeded such religious rights. Inmates had this to say:

I say that whilst I worship in this prison I am unable to worship as I want. The prison rules help us but at times it does not. ... My problem with the rules is that when it is even 10am and we are still worshipping we hear the officers shouting at us telling us to get into our cells. ...because a high-level government official is visiting. This makes worshipping in the prison quite problematic. When this happens and you don't have faith you may stop worshipping. (Abraham, inmate, religious leader, 2017)

Two ex-convicts reiterated the position of rigid rules by saying that:

Practicing religion in prison was sometimes very difficult. For example, we the Muslims individually prayed in our cells instead of praying together at dawn. We could not pray together because of rigid rules in the prison. (Bugum, ex-convict, 2017)

At times you could even be asked to stop a church activity for something else. The restrictions were too much. I remember there was a time our crusade had to be postponed because some prison officials from the prison headquarters were visiting the facility. (Baron, ex-convict, 2017)

The data divulge that although inmates have rights, it does not imply they always have a constitutional right to do things or worship the way they want because of religious faith.

28 See Jones, 1994 
The rights of prisoners to practice their religion are balanced against prison rules. These rights, in practice, revealed that the abstract principle of humane treatment underpinning the respect for rights in prison was often ignored and reduced to mere formal respect for rules. Tacitly, the power exercised by the prison diminishes the inmate's full claim of religious rights. This argument, to some extent, denotes that the motives related to an inmate's religious rights are definite within that space, nonetheless are non-definite outside of that space. Though competing rights, as the data suggest, officers place other prison rules, whether formal or informal, above the inmate's religious rights, and by this sidestep the inmate's rights to ensure penal management. This shows that the religious rights of inmates are conclusive within some delimited space. Likewise, it also shows that rights have qualifications that determine when it is applicable and when it is not. ${ }^{29}$

One of the key distinctions between prison religious practices is the adaptability of the adherents. The precept of Islamic practice is to pray five times a day, whilst some evangelicals are also expected to engage in all-night prayers. These practices are certainly not possible under the safe custodial programme of the prison administration. Despite the challenges posed by other contending interests, inmates inspired each other through their religious beliefs to respect prison rules. This is captured in a statement made by two inmates:

We do not have the freedom to worship Allah the way we want in this prison. The truth is that our freedom has already been denied us so we have to act according to the rules of the prison. We only have to submit to the officers so that we don't have problems with them.... we are under the law of the prison. Our beliefs tell us to respect authorities and laws. ...so we have no option than to see to it that their rules are implemented to the latter. This is what Allah expects of us. (Salisu, inmate, religious leader, April, 2017).

We respect prison rules. I would not even call it prison rules. I would say the rules are God's rules (Yaw, inmate, 2018).

Apart from inspiring each other, some inmates explained their reasons for respecting prison rules in the context of their religion.

I am a changed person not because the prison is a difficult place but because I have now come into contact with the light (Jesus). (Moses, inmate, 2018).

29 See Shafer-Landau, 1995

12 || UCC Faculty of Law Journal 
...not because officers are strict with enforcing the prison laws ...but because my Quran tells me so. (Musah, inmate, 2018).

The Christian visiting clergy stated;

The Bible instructs them (prisoners) to obey authorities (Warders). Refusing their (warders) instructions is disobedience to God.

The Muslim clergy reiterated that;

Islam is a religion of peace and law. Allah commands every person to respect the laws of his/her nation. ...you have to strictly follow Allah's rule so that you don't have problems with authority. Following Allah's rule is following the prison rules. And doing this means you are fulfilling Allah's commandments.

From the above, religion, by default, is an agent of social control of the inmates, as it anchors and reinforces the prison rules by which inmates conduct themselves. This shows how religion is knotted into the social order of the prison as it reinforces and gives legitimation to prison values and norms. ${ }^{30}$ All these show how inmates are explaining away their religious reality through their social constructs. ${ }^{31}$

In addition, the data reveal inmates' self-conception: hardly any inmates interviewed talked about the impact of the prison rules and regulations changing their personality and their lives. Most explained the changes in their character purely in the context of the transformative power of religion. That is, inmates obeyed the prison rules and regulations simply because their religions warrant obedience to authority. It is indeed not prison rules and regulations that alter the behaviour of inmates but rather the ideological justification of their religious faith. This analysis shows that religion is a strong pillar for inmates and of the prison. It is also seen that with the prison as an ordered 'society', of a legal order, religion is the organising principle of social control. This explains what constitutes inmates' subjugation to the prison bureaucracy. To this extent, what might have been a recurrence of mayhem within the prison has been put under control by religion. In this light, religion as social control should not be examined on its failures - i.e. clouding inmates' ability to fight their terrible prison conditions, but on its achievements; on nothing less than the social order of the prison.

30 See Durkheim, 1954

31 See Berger \& Luckmann, 1967 


\section{Conclusion}

This study examined the rights of inmates in the context of their religion and what constituted their subjugation to prison authority. The pragmatist approach of mixedmethod was used for data gathering. Based on the analyses above, this study concludes that the legal regimes on prison recognize freedom of religion as well as freedom off religion; a mark of respect of inmates' civil rights. Regardless of these rights, inmates were at times restricted by prison warders depending on the assumed consequences of allowing such religious practices. The inmate's rights to religious practices do not imply that all kinds of religion can be practiced in prison. This means that whilst there is no anarchy in terms of inmates' religious rights and practices, at times prison officers circumvent the laws and rights of inmates to succeed in penal management.

Inmates take to heart the instructions of their religion to respect prison rules and to show deference to prison officials even where inmates were aware of the violations of their rights. Worthy of note is that it is not the official prison rules and regulations per se that changed any individual inmate. It is the pervasiveness and internalization of religious principles that appeared to have altered the personality of inmates and maintained prison order. If the prison rules aim at subduing the inmates to the prescriptions of the institution, then it is the religion that provides the ideological justifications for why inmates abide by the rules. For some inmates, respecting the prison rules was about upholding the authority of their deities. 


\section{References}

Agnew, R. T. Foundation for a General Strain Theory of Crime and Delinquency. (Criminology, 1992). 30(1), 47-87.

Attafuah, K. Confronting the Horrors Within: A Trilogy of Compelling Human Rights Violations in Ghana's Criminal Justice System -- Police Killing of Robbery Suspects, Judicial Abuse of Bail, and Prison Conditions (2013). Available at http://studylib.net/doc/7590809/cle-2013-atrilogy-of-human-rights-violations-incriminal... retrieved on 23/03/2017.

Berger, P., \& Luckmann, T. The social construction of reality: a Treatise in the Sociology of Knowledge. (Penguin, Harmondsworth, 1967).

Burr, V. Social Constructionism (2nd Ed). (London: Routledge, 2003).

Clear, T. R., Bruce, D. S., Harry, R. D., Kelly, L. Hardyman, P., \& Shapiro, C. Religion in prison: Final report, (School of Criminal Justice, Rutgers University, Newark, New Jersey, 1992).

Constitution of the Republic of Ghana. (Ghana Publishing Company Limited, Assembly Press, Accra, 1992).

Cullen, F. T., \& Jonson, C. L. Correctional theory: Context and consequences. (Thousand Oaks, Calif: SAGE, 2012).

Durkheim, E. The elementary forms of the religious life. (London: George Allen \& Unwin Ltd., 1912, pp. 201).

Durkheim, E. The elementary forms of religious Life, (Oxford, Oxford University Press, 1954).

Gaur, M. Role of religion in resocialization of prisoners. (Unistar Books Pvt. Ltd., 2011).

Hohfeld, W. Fundamental Legal Conceptions, W. Cook (ed.), (New Haven: Yale University Press, 1919).

Jensen, G. Sociology of delinquency: Current issues. (London: Sage, 1981).

Jones, P. Rights, (New York: St. Martin's Press, 1994).

Kymlicka, W. Multicultural Citizenship: A Liberal Theory of Minority Rights, (Clarendon Press \& Oxford University Press, 1995). 
Prison Regulations. 1958.

Prison Service Decree. (1972). NRCD 46.

Prison Standing Orders. (1960).

Schwandt, T. A. Three epistemological stances for qualitative inquiry: Interpretivism, hermeneutics and social constructionism. In Denzin, N. and Lincoln, Y (Eds.), The Landscape of Qualitative Research: Theories and issues. (Thousand Oaks, CA: Sage, 2003).

Shafer-Landau, R. "Specifying Absolute Rights", (Arizona Law Review, 1995, 37: 209 24).

Stansfield, R., Mowen, T. J., O'Connor, T., \& Boman, J. H. Role of Religious Support in Re-entry: Evidence from the SVORI Data. Journal of Research in Crime and Delinquency, 2017 54(1), 111-145.

Universal Declaration of Human Rights, (United Nations Publication, 2015). [Retrieved from http://www.un.org/en/udhrbook/pdf/udhr_booklet_en_web.pdf on 08/09/2018]

Witte, J., \& Green, M. C. Religion and Human Rights: An Introduction. (Oxford University Press, 2015).

Yin, E. T. Religion as an Organising Principle in Ankaful Maximum Security Prison, Ghana. Unpublished PhD Thesis, Department of Sociology and Anthropology, University of Cape Coast, 2018.

Zellick, G. 'Corporal Punishment in the Isle of Man', International Comparative Law Quarterly, 1978, 27, pp. 665-671. 